\title{
Effects of ocean acidification on calcification of symbiont-bearing reef foraminifers
}

\author{
K. Fujita ${ }^{1}$, M. Hikami ${ }^{1,2}$, A. Suzuki ${ }^{3}$, A. Kuroyanagi ${ }^{2}$, K. Sakai ${ }^{4}$, H. Kawahata ${ }^{2}$, and Y. Nojiri ${ }^{5}$ \\ ${ }^{1}$ Department of Physics and Earth Sciences, University of the Ryukyus, Okinawa, Japan \\ ${ }^{2}$ Atmosphere and Ocean Research Institute, The University of Tokyo, Kashiwa, Japan \\ ${ }^{3}$ Geological Survey of Japan, National Institute of Advanced Industrial Science and Technology (AIST), Tsukuba, Japan \\ ${ }^{4}$ Sesoko Station, Tropical Biosphere Research Center, University of the Ryukyus, Okinawa, Japan \\ ${ }^{5}$ Center for Global Environmental Research, National Institute for Environmental Studies, Tsukuba, Japan
}

Received: 2 February 2011 - Published in Biogeosciences Discuss.: 25 February 2011

Revised: 27 July 2011 - Accepted: 1 August 2011 - Published: 4 August 2011

\begin{abstract}
Ocean acidification (decreases in carbonate ion concentration and $\mathrm{pH}$ ) in response to rising atmospheric $p \mathrm{CO}_{2}$ is generally expected to reduce rates of calcification by reef calcifying organisms, with potentially severe implications for coral reef ecosystems. Large, algal symbiontbearing benthic foraminifers, which are important primary and carbonate producers in coral reefs, produce high-Mg calcite shells, whose solubility can exceed that of aragonite produced by corals, making them the "first responder" in coral reefs to the decreasing carbonate saturation state of seawater. Here we report results of culture experiments performed to assess the effects of ongoing ocean acidification on the calcification of symbiont-bearing reef foraminifers using a high-precision $p \mathrm{CO}_{2}$ control system. Living clone individuals of three foraminiferal species (Baculogypsina sphaerulata, Calcarina gaudichaudii, and Amphisorus hemprichii) were subjected to seawater at five $p \mathrm{CO}_{2}$ levels from 260 to $970 \mu \mathrm{atm}$. Cultured individuals were maintained for about 12 weeks in an indoor flow-through system under constant water temperature, light intensity, and photoperiod. After the experiments, the shell diameter and weight of each cultured specimen were measured. Net calcification of B. sphaerulata and $C$. gaudichaudii, which secrete a hyaline shell and host diatom symbionts, increased under intermediate levels of $p \mathrm{CO}_{2}(580 \mathrm{and} / \mathrm{or} 770 \mu \mathrm{atm})$ and decreased at a higher $p \mathrm{CO}_{2}$ level $(970 \mu \mathrm{atm})$. Net calcification of A. hemprichii, which secretes a porcelaneous shell and hosts dinoflagellate symbionts, tended to decrease at elevated $\mathrm{pCO}_{2}$. Observed different responses between hyaline and porcelaneous species are possibly caused by the relative importance of
\end{abstract}

Correspondence to: K. Fujita

(fujitaka@sci.u-ryukyu.ac.jp) elevated $p \mathrm{CO}_{2}$, which induces $\mathrm{CO}_{2}$ fertilization effects by algal symbionts, versus associated changes in seawater carbonate chemistry, which decreases a carbonate concentration. Our findings suggest that ongoing ocean acidification might favor symbiont-bearing reef foraminifers with hyaline shells at intermediate $p \mathrm{CO}_{2}$ levels (580 to $770 \mu \mathrm{atm}$ ) but be unfavorable to those with either hyaline or porcelaneous shells at higher $p \mathrm{CO}_{2}$ levels (near $1000 \mu \mathrm{atm}$ ).

\section{Introduction}

The oceans have taken up about one-third of the anthropogenic carbon dioxide released into the atmosphere over the past 200 years (Sabine et al., 2004). According to the Intergovernmental Panel on Climate Change (IPCC) Special Report on Emission Scenarios (SRES), atmospheric $\mathrm{CO}_{2}$ will rise further, up to a partial pressure of 500-1000 $\mu$ atm by the end of the century (Meehl et al., 2007). This absorption of $\mathrm{CO}_{2}$ into the surface ocean changes seawater chemistry, resulting in decreases in $\mathrm{pH}$ and carbonate ion concentration, and increases in the concentrations of bicarbonate and hydrogen ions. It will also lead to a decrease in the saturation state of seawater with respect to calcite and aragonite, two common forms of calcium carbonate secreted by marine calcifying organisms (Orr et al., 2005). Calcification of marine calcareous organisms is strongly dependent on the carbonate saturation state of seawater, suggesting that ocean acidification will adversely affect marine calcifying taxa, with potentially severe implications for marine ecosystems such as coral reefs (Kleypas et al., 1999).

Published by Copernicus Publications on behalf of the European Geosciences Union. 
Culture experiments with reef calcifying organisms such as corals, coralline algae, molluscs, and foraminifers suggest that ocean acidification will adversely impact their calcification (e.g. Gattuso et al., 1998; Kuffner et al., 2008; Kuroyanagi et al., 2009; Ries et al., 2009), leading to a reduction in coral-reef biodiversity and the net accumulation of reef carbonates in the future (Hoegh-Guldberg et al., 2007). Large, reef-dwelling benthic foraminifers (defined as mature individuals $>1 \mathrm{~mm}$ in diameter) are shelled protists that are host to algal endosymbionts (Lee, 1998; Hallock, 1999). They are one of the primary producers and carbonate producers in coral reefs (Hallock, 1981; Langer et al., 1997; Hohenegger, 2006; Fujita and Fujimura, 2008), secreting high-magnesium calcite (HMC; Raja et al., 2005), the solubility of which can exceed that of aragonite at a similar seawater $p \mathrm{CO}_{2}$ level (Morse et al., 2006). Therefore, reef foraminifers with high-magnesium calcite shells may be the "first responders" among reef calcifying organisms to the decreasing saturation state of seawater caused by ocean acidification.

During calcification, foraminifers are able to elevate the $\mathrm{pH}$ at the site of calcification (vesicles or seawater vacuoles) by one unit above seawater pH (Erez, 2003; Bentov et al., 2009; de Nooijer et al., 2009). In acidified seawater, foraminifers would require more energy to elevate the intracellular $\mathrm{pH}$, leading to a decrease in calcification. Previous culturing results have indicated that shell weights of both planktonic and benthic foraminifers reduce with decreasing $\left[\mathrm{CO}_{3}^{2-}\right]$ or pH (Bijma et al., 1999, 2002; Dissard et al., 2010; Lombard et al., 2010). Calcification (measured as increments of shell weight and diameter) of Marginopora, a large, dinoflagellate symbiont-bearing benthic foraminifer, is reduced as $\mathrm{pH}$ becomes lower (Kuroyanagi et al., 2009). Culture experiments using ${ }^{14} \mathrm{C}$ tracer techniques of reef foraminifers have also shown that the carbon uptake ratio is dependent on $\mathrm{pH}$ and concentrations of inorganic carbon and calcium, and decreases when the $\mathrm{pH}$ or the concentrations of these elements are lower than those of the present seawater (ter Kuile et al., 1989).

However, the effects of ocean acidification on calcification of diverse large, algal symbiont-bearing and reef-dwelling benthic foraminifers have been assessed in only one species (Marginopora kudakajimensis; Kuroyanagi et al., 2009). Recent studies have shown that the response of marine calcifying organisms to ocean acidification varies both within and among species (e.g. Fabry, 2008; Langer et al., 2009; Ries et al., 2009; Ridgwell et al., 2009). Moreover, in our previous study (Kuroyanagi et al., 2009), we controlled the $\mathrm{pH}$ by adding an acid or base, rather than by bubbling $\mathrm{CO}_{2}$ enriched air through the seawater, though the latter would better reproduce the present anthropogenic changes and the ocean's response. Therefore, in this study, we conducted a culture experiment using a high-precision $p \mathrm{CO}_{2}$ control system to assess the effect of ocean acidification on calcification of symbiont-bearing reef foraminifers.

\section{Materials and methods}

\subsection{Target species}

Three species of large, algal symbiont-bearing benthic foraminifers were selected for this study: Baculogypsina sphaerulata (Parker and Jones), Calcarina gaudichaudii d'Orbigny in Ehrenberg, and Amphisorus hemprichii Ehrenberg. These species are commonly found on macrophytes on coral-reef flats in the northwest Pacific (e.g. Hohenegger, 1994) and are important primary producers and carbonate producers in their environments (e.g. Sakai and Nishihira, 1981; Hohenegger, 2006; Fujita and Fujimura, 2008). Shells of all three species are composed of high-magnesium calcite (HMC; approx. $10 \mathrm{Mg} \mathrm{mol} \mathrm{\% ;} \mathrm{Saraswati} \mathrm{et} \mathrm{al.,} \mathrm{2004).} \mathrm{Shell}$ walls of B. sphaerulata and $C$. gaudichaudii are perforate and have a hyaline (i.e. clear, glassy) appearance, whereas those of A. hemprichii are imperforate and appear porcelaneous (i.e. shiny, white, and smooth like porcelain). Baculogypsina sphaerulata and $C$. gaudichaudii are host to diatom endosymbionts, whereas A. hemprichii is host to dinoflagellate endosymbionts (Lee, 1998). In addition, these three species have been observed to reproduce asexually during spring and summer (Sakai and Nishihira, 1981; Hohenegger, 2006). Thus, asexually reproduced clone individuals can be used for culture experiments to exclude the effect of genetic variability on the experimental results. For more detailed information on the taxonomy, biology, and ecology of these species, see Röttger and Krüger (1990) and Hohenegger (1994).

\subsection{Maintenance until asexual reproduction}

Adult individuals just before asexual reproduction (agamont or shizont) were collected during low tide on nearshore reef flats: B. sphaerulata and C. gaudichaudii northeast of Ikei Island, Okinawa, Japan $\left(26^{\circ} 23^{\prime} \mathrm{N}, 128^{\circ} 00^{\prime} \mathrm{E}\right)$ on 26 April and 22 May 2009, and A. hemprichii on a reef moat along the Oudo coast, south of Okinawa Island $\left(26^{\circ} 05^{\prime} \mathrm{N}\right.$, $127^{\circ} 42^{\prime} \mathrm{E}$ ) on 28 May 2009. Collected individuals were maintained separately in small Petri dishes filled with natural seawater at room temperature (approximately $25^{\circ} \mathrm{C}$ ) under a natural light:dark cycle near a window (light intensity, $\sim 100 \mu \mathrm{mol} \mathrm{m}^{-2} \mathrm{~s}^{-1}$ ). Because $C$. gaudichaudii and B. sphaerulata are commonly found in high-energy reef-flat environments (Hohenegger, 1994), these species were maintained under continuous water motion produced by using a continuous-action shaker (approximately $30 \mathrm{rpm}$; in vitro Shaker, Wave-PR, TAITEC Inc., Saitama, Japan). In contrast, A. hemprichii individuals were maintained under stagnant conditions on a flat shelf, because they are commonly found in relatively calm reef-moat environments (Hohenegger, 1994). These individuals were not fed during maintenance, and the culture medium was changed weekly. 


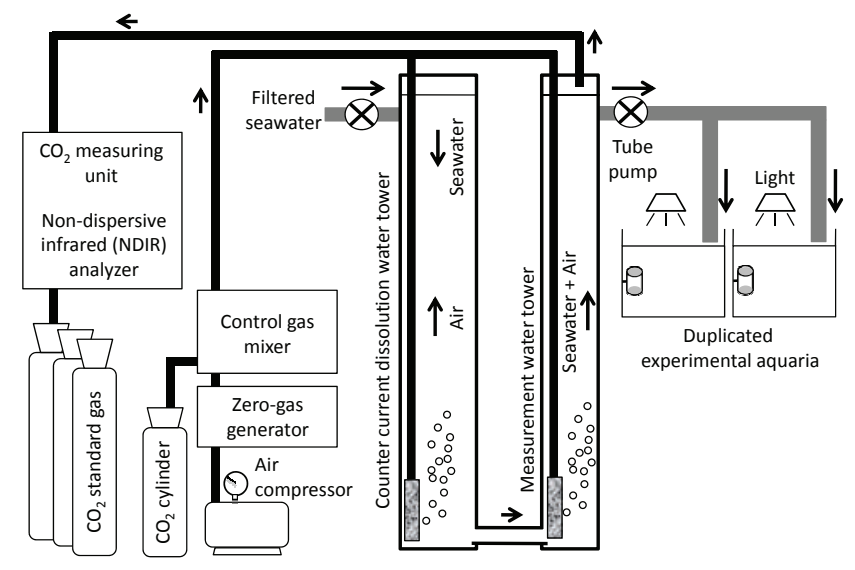

Fig. 1. The schematic diagram of culturing set-up. See the text for explanation.

After a few weeks, these adult individuals reproduced asexually. Juveniles of the clone populations were kept under the same conditions as the adults for 4 to 6 weeks until the experiments were started. To determine differences in characteristics within species under experimental conditions, two clone populations of each species were used, tagged as populations $\alpha$ (alpha) and $\beta$ (beta).

\subsection{High-precision $p \mathrm{CO}_{2}$ control system}

Clone individuals of the three foraminiferal species were placed into culture cages and subjected to seawater with different $p \mathrm{CO}_{2}$ levels. $p \mathrm{CO}_{2}$ in each culture cage was adjusted by bubbling $\mathrm{CO}_{2}$ gas through the seawater, and a constant $p \mathrm{CO}_{2}$ level was maintained by a high-precision $p \mathrm{CO}_{2}$ control system developed with the cooperation of Kimoto Electric Co., Ltd. (Osaka, Japan). This system is composed of $\mathrm{CO}_{2}$ dissolution and measurement towers (height, $1.78 \mathrm{~m}$ ), into which gaseous $\mathrm{CO}_{2}$ is dissolved in seawater by bubbling it from the bottom of the towers (Fig. 1). The seawater $p \mathrm{CO}_{2}$ is continually monitored in the equilibrated air flowing out from the measurement tower surface and adjusted as needed by controlling the $\mathrm{CO}_{2}$ concentration in the air by mixing $\mathrm{CO}_{2}$ and dilution-air (dried air with a low $\mathrm{CO}_{2}$ concentration) into the filtered (pore size, $1 \mu \mathrm{m}$ ) seawater.

The $p \mathrm{CO}_{2}$ of the culture medium was adjusted to one of five $p \mathrm{CO}_{2}$ levels (approximately 260, 360, 580, 770, and $970 \mu$ atm, Table 1) corresponding to the estimated preindustrial value, the present value, and future values predicted by IPCC SRES (Meehl et al., 2007), respectively. Seawater temperature and chemistry (salinity, $\mathrm{pH}$, and total alkalinity) were measured twice a week, and the averaged values were used for calculating the saturation state of seawater with respect to calcite (Table 1).

\subsection{Culture protocol}

Each foraminifer culture cage consisted of a clear vinyl hose $(5 \mathrm{~cm}$ long; inside diameter, $2.5 \mathrm{~cm})$ with a cell strainer $(100 \mu \mathrm{m}$ mesh, BD Falcon, Inc) at each end. For each clone population, 40 individuals of each species (i.e. a total of 120 individuals per cage) were put into a cage. A set of five cages for the five $p \mathrm{CO}_{2}$ levels were prepared for each of the two clone populations $\alpha$ and $\beta$. Before the start of experiment, another 40 clone individuals of each species were preserved in ethanol. Each cage was placed in a water bath and attached to the tank wall with a suction cup. Thus, there were a total of 10 water baths (five treatments $\times$ two clone populations). Seawater within the culture cages was circulated by fixing them in a path of a water jet within the water bath. Culture cages containing clone individuals were maintained for approximately 12 weeks (from 6 July to 30 September 2009) at a constant water temperature $\left(27.5 \pm 0.1{ }^{\circ} \mathrm{C}\right)$, light intensity $\left(60 \mu \mathrm{mol} \mathrm{m}{ }^{-2} \mathrm{~s}^{-1}\right)$, and photoperiod (12h). During the culture experiments, filamentous algae attaching to the surfaces of the culture cages were removed biweekly with brushes. Small air bubbles inside the cages, probably produced by the photosynthesis of the algal symbionts, were removed with a pipette.

At the end of the experiment, the cages were removed from the water baths and kept cool until later analysis. Cultured individuals were picked from each cage, cleaned with a brush and distilled water, and air-dried. Of the 40 cultured individuals, 20 were selected randomly for measurements, excluding dead individuals (i.e. those that did not grow or had no protoplasm). Mortality during the experiments was very low, less than $2.5 \%$ for each population. Twenty individuals from those preserved in ethanol at the start of the experiment (hereafter, "initial individuals") were also randomly selected for comparison with the cultured individuals.

\subsection{Measurements}

The shell diameter and shell weight of each initial and cultured individual was measured. The shell diameter (the average of the maximum diameter from the final chamber and that crossing the first at the center of the test and perpendicular to it) was measured to the nearest $1 \mu \mathrm{m}$ on microscope photographs using image analysis software (Photomeasure, Kenis Inc., Osaka, Japan). Shell weight was measured to the nearest $0.1 \mu \mathrm{g}$ using a microbalance (Thermo Cahn C-35 microbalance, Thermo Electron Corporation).

Growth (calcification) rates were estimated from the increment of shell diameter and weight during the experimental period. Although time-course measurements have not been conducted in this experiment to avoid the loss of cultured specimens and to minimize stress to them during manipulation, our previous culture experiments using clones of Marginopora kudakajimensis (Kuroyanagi et al., 2009) statistically confirmed that shell diameter increased with time 
Table 1. Mean physical and chemical conditions in each $p \mathrm{CO}_{2}$ treatment. Standard deviations are shown for $\mathrm{pH}_{\mathrm{T}}$ and $p \mathrm{CO}_{2}$. The mean salinity and total alkalinity, which were measured repeatedly during the experiments, were 34.4 and $2188 \mu \mathrm{mol} \mathrm{kg}^{-1}$, respectively. The value of DIC (dissolved inorganic carbon), $\Omega_{\text {cal }}$ and $\Omega_{\text {arg }}$ (saturation state of seawater with respect to calcite and aragonite) was calculated from the total alkalinity and $p \mathrm{CO}_{2}$.

\begin{tabular}{lllllll}
\hline Treatment & $\begin{array}{l}\text { Temperature } \\
\left({ }^{\circ} \mathrm{C}\right)\end{array}$ & $\mathrm{pH}_{\mathrm{T}}$ at $25^{\circ} \mathrm{C}$ & $\begin{array}{l}p \mathrm{CO}_{2} \\
(\mu \mathrm{atm})\end{array}$ & $\begin{array}{l}\mathrm{DIC} \\
\left(\mu \mathrm{mol} \mathrm{kg}{ }^{-1}\right)\end{array}$ & $\Omega_{\text {cal }}$ & $\Omega_{\text {arg }}$ \\
\hline Preindustrial & 27.5 & $8.170 \pm 0.028$ & $261 \pm 29$ & 1796 & 6.39 & 4.24 \\
Present & 27.4 & $8.072 \pm 0.033$ & $360 \pm 19$ & 1865 & 5.32 & 3.53 \\
Future 1 & 27.5 & $7.926 \pm 0.039$ & $580 \pm 30$ & 1958 & 3.91 & 2.60 \\
Future 2 & 27.5 & $7.826 \pm 0.035$ & $774 \pm 56$ & 2007 & 3.18 & 2.11 \\
Future 3 & 27.6 & $7.756 \pm 0.038$ & $972 \pm 43$ & 2043 & 2.69 & 1.78 \\
\hline
\end{tabular}

over the range of seawater $\mathrm{pH}$ examined (from 7.7 to 8.3; NBS scale). On the other hand, culturing studies of other species of reef foraminifers (Amphistegina spp.) showed that growth rates of juvenile clones were faster than those of matured ones (Hallock et al., 1986). Thus, calcification rates obtained in this experiment are averaged or underestimated.

\subsection{Statistical analysis}

The shell diameter and weight data sets were analyzed by one-way analysis of variance (ANOVA) for differences among the five $p \mathrm{CO}_{2}$ levels. When significant differences were observed within a data set, the difference between each pair of means was analyzed with a Tukey's Honestly Significant Difference (HSD) test. These statistical analyses were performed with JMP 7.0.2 (SAS Institute Inc.).

\section{Results}

All individuals cultured at different $p \mathrm{CO}_{2}$ levels grew more than twice as large as the initial individuals during the experimental period (Fig. 2). SEM images of cultured specimens did not show any traces of shell dissolution. Shell weight was positively correlated with shell diameter, but the statistical analysis indicated that shell weight was more dependent on $p \mathrm{CO}_{2}$ than shell diameter, as reported by Kuroyanagi et al. (2009) as well. This difference is partly because shell diameter does not exactly reflect three-dimensional shell growth, in particular in B. sphaerulata and C. gaudichaudii, which have subglobular to bilenticular shells with spines (Fig. 2). Thus, the following description of culturing results is focused on foraminiferal shell weight.

\subsection{Baculogypsina sphaerulata}

The mean shell weight of initial individuals of B. sphaerulata was about $4 \mu \mathrm{g}$ for both populations (Fig. 3). At the end of experiment, the mean shell weight of the cultured individuals varied from 15 to $25 \mu \mathrm{g}$. The shell weight was relatively heavier at intermediate $p \mathrm{CO}_{2}$ levels in both clone

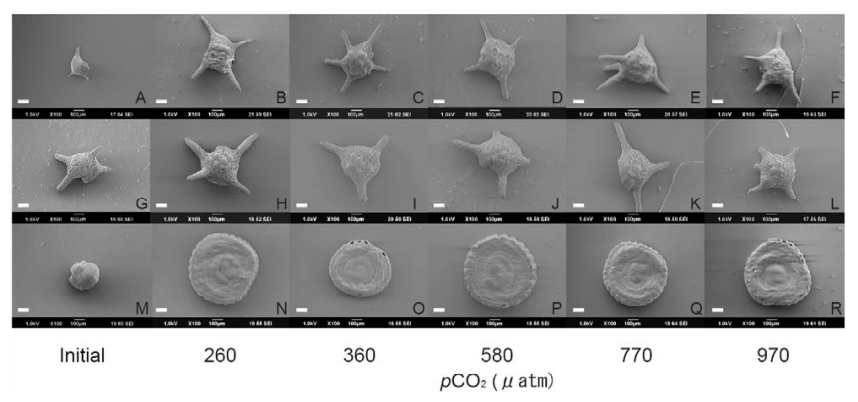

Fig. 2. SEM images of cultured individuals at various $p \mathrm{CO}_{2} \mathrm{lev}$ els $($ scale bar $=100 \mu \mathrm{m})$. Photographs are shown for average-sized specimens from the population $\alpha$ of each species. (A to F) Baculogypsina sphaerulata, ( $\mathrm{G}$ to $\mathrm{L}$ ) Calcarina gaudichaudii, ( $\mathrm{M}$ to $\mathrm{R})$ Amphisorus hemprichii. (A, G, M) initial individuals, (B, H, N) specimens subjected to $260 \mu \mathrm{atm},(\mathrm{C}, \mathrm{I}, \mathrm{O})$ specimens subjected to $360 \mu \mathrm{atm},(\mathrm{D}, \mathrm{J}, \mathrm{P})$ specimens subjected to $580 \mu \mathrm{atm},(\mathrm{E}, \mathrm{K}, \mathrm{Q})$ specimens subjected to $770 \mu \mathrm{atm},(\mathrm{F}, \mathrm{L}, \mathrm{R})$ specimens subjected to $970 \mu \mathrm{atm}$.

populations. One-way ANOVA indicated significant differences in shell weight among the different $p \mathrm{CO}_{2}$ levels in both populations $(F=4 ; P<0.001$ for population $\alpha$, $P<0.0001$ for population $\beta$ ). Tukey's HSD post hoc test of each population showed that individuals grown at a $p \mathrm{CO}_{2}$ of $770 \mu$ atm had significantly heavier shell weights than those grown at 360 or $970 \mu$ atm $(P<0.05)$. Mean shell weights of individuals grown at a $p \mathrm{CO}_{2}$ of $580 \mu \mathrm{atm}$ were significantly heavier than those of individuals grown at $970 \mu \mathrm{atm}$ $(P<0.05)$. In population $\beta$, individuals grown at $580 \mu \mathrm{atm}$ were also significantly heavier than those grown at 260 or $360 \mu$ atm $(P<0.05)$. Moreover, in both populations, individuals grown at $260 \mu \mathrm{atm}$ were found to be heavier than those grown at $360 \mu \mathrm{atm}$, although mean shell weight was not statistically significant between these two treatments.

\subsection{Calcarina gaudichaudii}

The mean shell weight of initial individuals of $C$. gaudichaudii was about 16 and $13 \mu \mathrm{g}$ for population $\alpha$, and $\beta$, 

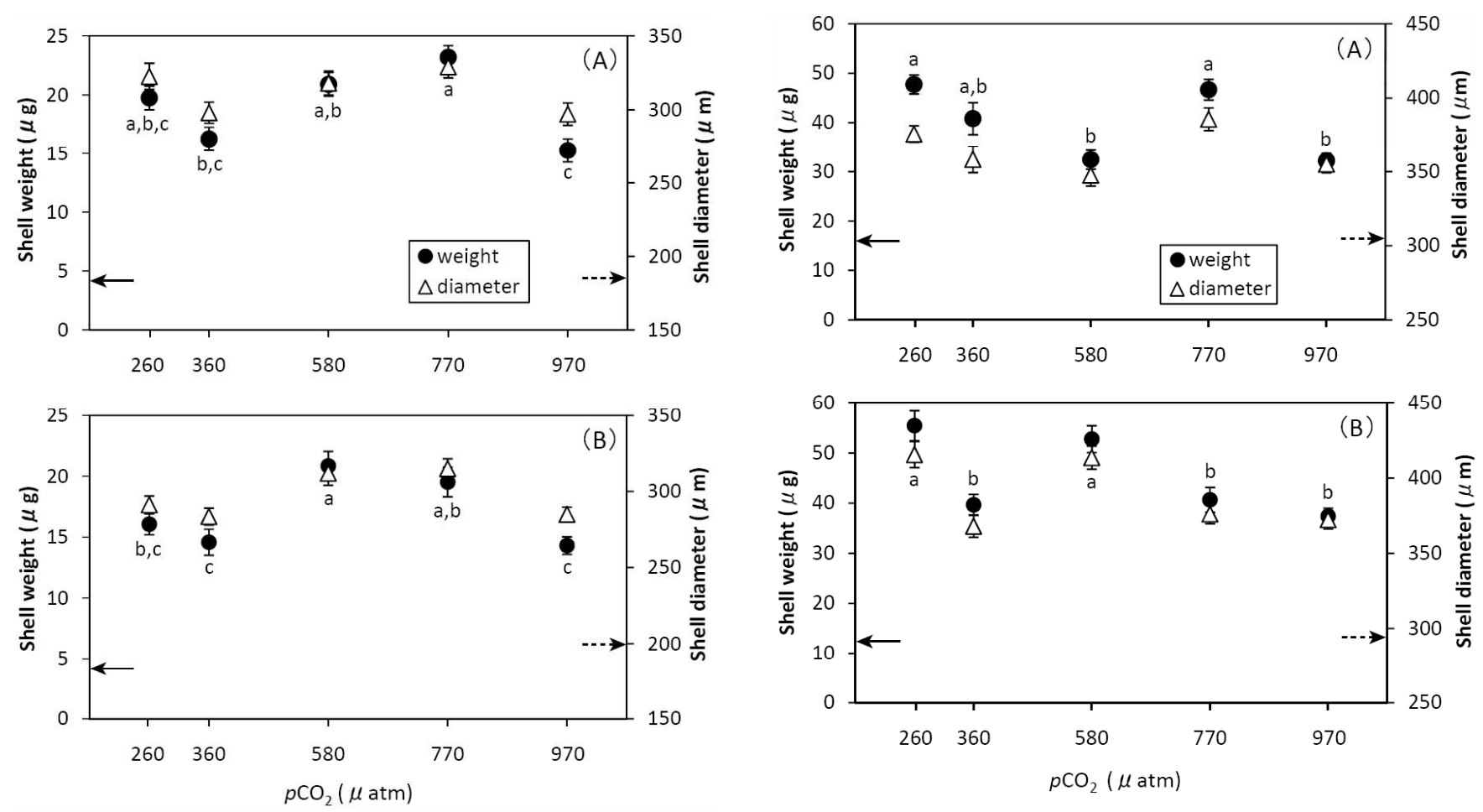

Fig. 3. Mean shell diameter and weight of Baculogypsina sphaerulata after culture for about 12 weeks at five $p \mathrm{CO}_{2}$ levels. Values are means $\pm \mathrm{SE}$ of the 20 clone individuals sampled in each treatment. Different letters above plotted treatment values indicate a significant difference $(\alpha=0.05)$ in shell weight according to Tukey's HSD post hoc test. Dashed and solid arrows show mean shell diameter and mean weight of clone individuals, respectively, at the start of the experiment. (A) Population $\alpha$, (B) population $\beta$.

respectively (Fig. 4). At the end of experiment, the mean shell weight of the cultured individuals varied from 30 to $50 \mu \mathrm{g}$ in population $\alpha$, and from 35 to $55 \mu \mathrm{g}$ in population $\beta$. It was generally lower at elevated $p \mathrm{CO}_{2}$, but higher at intermediate $p \mathrm{CO}_{2}$ levels. One-way ANOVA indicated significant differences in shell weight among different $p \mathrm{CO}_{2}$ levels in both populations $(F=4, P<0.0001)$. Tukey's HSD post hoc test of each population showed that individuals grown at a $p \mathrm{CO}_{2}$ of $260 \mu \mathrm{atm}$ had significantly heavier shell weights than those grown at $970 \mu$ atm $(P<0.05)$. In population $\alpha$, individuals grown at 260 and $770 \mu$ atm were significantly heavier than those grown at 580 or $970 \mu$ atm $(P<0.05)$. In population $\beta$, individuals grown at 260 and $580 \mu \mathrm{atm}$ were significantly heavier than those grown at 360 , 770 , or $970 \mu$ atm $(P<0.05)$.

\subsection{Amphisorus hemprichii}

The mean shell weight of initial individuals of $A$. hemprichii was about 5 and $9 \mu \mathrm{g}$ for population $\alpha$ and $\beta$, respectively (Fig. 5). At the end of experiment, the mean shell weight of the cultured individuals varied from 30 to $50 \mu \mathrm{g}$ in population

Fig. 4. Mean shell diameter and weight of Calcarina gaudichaudii after culture for about 12 weeks at five $p \mathrm{CO}_{2}$ levels. Values are means \pm SE of the 20 clone individuals sampled in each treatment. Different letters above plotted treatment values indicate a significant difference ( $\alpha=0.05$ ) in shell weight according to Tukey's HSD post hoc test. Dashed and solid arrows show mean shell diameter and weight of clone individuals, respectively, at the start of the experiment. (A) Population $\alpha$, (B) population $\beta$.

$\alpha$, and from 30 to $83 \mu \mathrm{g}$ in population $\beta$. The mean shell weight tended to decrease at elevated $p \mathrm{CO}_{2}$. One-way ANOVA indicated significant differences in shell weight among different $p \mathrm{CO}_{2}$ levels in both populations $(F=4$; $P<0.01$ for population $\alpha$, and $P<0.0001$ for population $\beta$ ). Tukey's HSD post hoc test showed that in population $\alpha$, individuals grown at a $p \mathrm{CO}_{2}$ of $580 \mu \mathrm{atm}$ had significantly heavier shell weights than those grown at 770 or $970 \mu \mathrm{atm}$ $(P<0.05)$. In population $\beta$, individuals grown at a $p \mathrm{CO}_{2}$ of $260 \mu \mathrm{atm}$ had significantly heavier shell weights than those grown at $p \mathrm{CO}_{2}$ levels of $580 \mu \mathrm{atm}$ or more $(P<0.05)$. Mean shell weights of individuals grown at $770 \mu$ atm were significantly lighter than those grown at other $p \mathrm{CO}_{2}$ levels in population $\beta(P<0.05)$.

\section{Discussion}

\subsection{Scrutiny of culture experiments}

Prior to discussing the effect of elevated seawater $p \mathrm{CO}_{2}$ on the calcification of symbiont-bearing reef foraminifers, we 

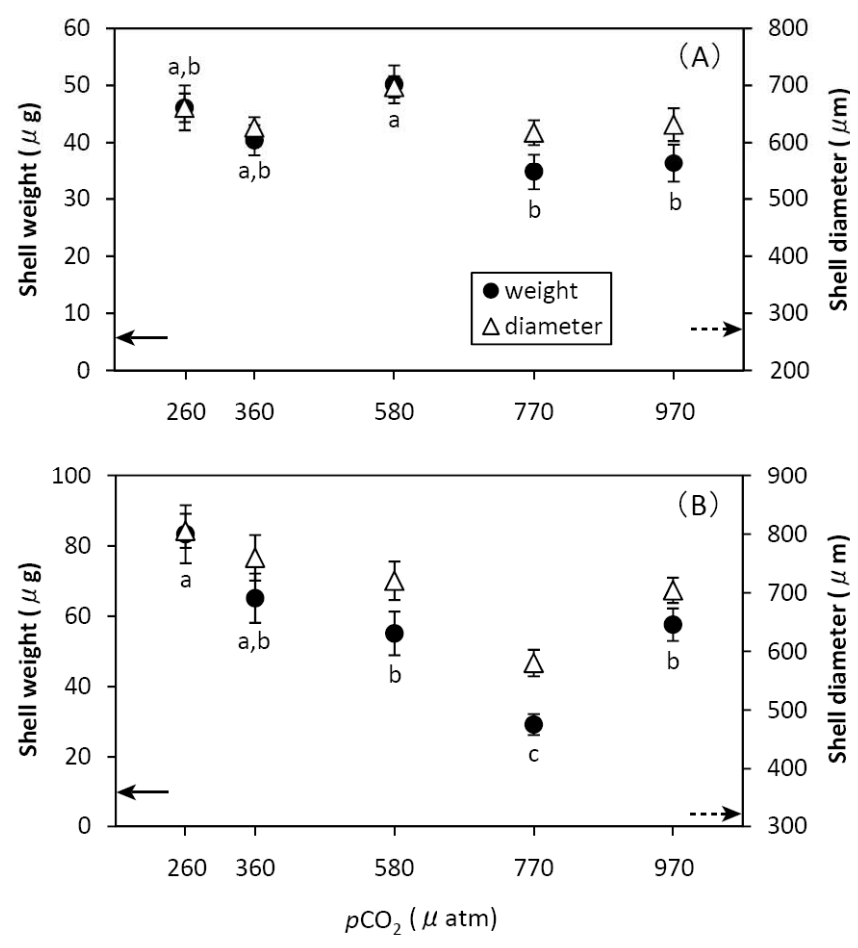

Fig. 5. Mean shell diameter and weight of Amphisorus hemprichii after culture for about 12 weeks at five $p \mathrm{CO}_{2}$ levels. Values are means \pm SE of the 20 clone individuals sampled in each treatment. Different letters above plotted treatment values indicate a significant difference $(\alpha=0.05)$ in shell weight according to Tukey's HSD post hoc test. Dashed and solid arrows show mean shell diameter and weight of clone individuals, respectively, at the start of experiment. (A) Population $\alpha$, (B) population $\beta$.

need to scrutinize causes producing variability in the data, possible problems associated with culturing experiments, and other factors that might affect calcification rates.

Reef foraminifers are usually subject to a large diurnal variation in reef-water $p \mathrm{CO}_{2}$, which ranges from 100 to $1000 \mu$ atm (e.g. Suzuki, 1994). Thus our studied ranges of carbonate chemistry are not beyond the tolerance limit of the physiology and growths of reef foraminifers. However, clone individuals were not pre-incubated in cultured conditions prior to experiments. The introduction to altered seawater carbonate chemistry may require time for foraminifers to acclimate and therefore cause them stressed particularly at the beginning of the experiment.

Environmental variables other than carbonate chemistry affect calcification rates. Light intensity in this experiment $\left(60 \mu \mathrm{mol} \mathrm{m}{ }^{-2} \mathrm{~s}^{-1}\right)$ was much darker than average daytime levels in their foraminiferal habitats as well as light saturation levels in a short-term light experiment (Fujita and Fujimura, 2008). Measurements of photosynthesis and respiration of the three foraminiferal species with algal symbionts in various temperatures (Fujita, unpublished data) indicate that net photosynthesis was enhanced in higher temperature $\left(30^{\circ} \mathrm{C}\right)$ than that in the cultured condition $\left(27.5^{\circ} \mathrm{C}\right)$. However, long-term exposures of high light and temperature may cause stress (bleaching) on symbiont-bearing foraminifers. Water motion also influences the metabolic activity of these foraminifers. Because B. sphaerulata and C. gaudichaudii live in high-energy environments and $A$. hemprichii prefers relatively calm environments (Hohenegger, 1994), water motions inside the cages might have been weaker than those in the natural environment, in particular for the two hyaline species. Furthermore, cultured foraminifers were not fed during the experiments. Lee et al. (1991) showed that food availability did not influence growth rates of symbiont-bearing perforate (hyaline) foraminifer ( $\mathrm{Am}$ phistegina lobifera), whereas imperforate (porcelaneous) foraminifers (Amphisorus hemprichii and Marginopora kudakajimensis) grew better in fed conditions than in unfed conditions. Therefore, all these variables might have not been optimum conditions for cultured foraminifers. Nevertheless, since cultured individuals were maintained in the homogeneous conditions except for $p \mathrm{CO}_{2}$, observed differences in the calcification rates can be interpreted to be caused by different $p \mathrm{CO}_{2}$ levels.

Experimental results indicate that responses of foraminiferal calcification (measured by the increment of shell weight and diameter) to different $p \mathrm{CO}_{2}$ levels varied between two clone populations within a species. The variability between clone populations suggests the presence of diverse genotypes or ecotypes within a foraminiferal species and/or a symbiotic algal type, which have different physiological adaptations to $p \mathrm{CO}_{2}$, as suggested for the cocolithophore Emiliania huxleyi (Langer et al., 2009; Ridgwell et al., 2009). Langer et al. (2009) demonstrated that four strains of E. huxleyi did not show a uniform response to carbonate chemistry changes, which likely has a genetic basis. Although the possibility of various genotypes or ecotypes has not yet been demonstrated in symbiont-bearing reef foraminifers, diverse genotypes have been found within a single morphospecies of planktonic foraminifers from geographically separated water masses (e.g. de Vargas et al., 2002).

The variability in average shell weight among five $p \mathrm{CO}_{2}$ treatments within a clone population is mostly due to different growth rates of the cultured specimens (i.e. the number of chambers added during the experimental period). Kuroyanagi et al. (2009) also showed both shell weight and diameter of Marginopora kudakajimensis decreased with lowering seawater $\mathrm{pH}$. Variability in shell wall thickness among individuals subjected to different $p \mathrm{CO}_{2}$ levels may be partly attributed to differences in shell weight, as shown in planktonic foraminifers (Barker and Elderfield, 2002; de Moel et al., 2009; Moy et al., 2009). De Moel et al. (2009) showed that lighter shells were produced in planktonic foraminifers influenced by ocean acidification and seasonal upwelling. Our previous experiment (Kuroyanagi et al., 2009) also showed the shell weight of Marginopora kudakajimensis decreased 
with lowering seawater $\mathrm{pH}$ for specimens with an identical shell diameter. Detailed SEM examinations are necessary to find differences in shell wall thickness of the cultured specimens among different $p \mathrm{CO}_{2}$ levels.

\subsection{Effects of $p \mathrm{CO}_{2}$ on the calcification of symbiont-bearing reef foraminifers}

As discussed above, experimental results in this study may contain some "noises" affecting calcification rates. Thus we discuss below mainly statistically significant results that were common to the two clone populations within a species.

Calcification was enhanced at intermediate $p \mathrm{CO}_{2}$ levels in the two species with a hyaline shell (B. sphaerulata at 580 and $770 \mu \mathrm{atm}$ and $C$. gaudichaudii at 580 or $770 \mu \mathrm{atm}$ ), compared with that at the present $p \mathrm{CO}_{2}$ level. In contrast, calcification in A. hemprichii did not increase significantly at intermediate $p \mathrm{CO}_{2}$ levels. Furthermore, calcification in all three species studied tended to be reduced at the highest $p \mathrm{CO}_{2}$ level (970 $\left.\mu \mathrm{atm}\right)$.

The result of the two hyaline species is similar to the findings of previous culture experiments by Iglesias-Rodrigues et al. (2008) and Ries et al. (2009). Iglesias-Rodrigues et al. (2008) reported increased calcification and net primary production in the coccolithophore Emiliania huxleyi at high $p \mathrm{CO}_{2}(750 \mu \mathrm{atm})$. Ries et al. (2009) obtained parabolic calcification response patterns (i.e. positive at intermediate $p \mathrm{CO}_{2}$ [600 to $\left.900 \mu \mathrm{atm}\right]$ and negative at the highest $p \mathrm{CO}_{2}$

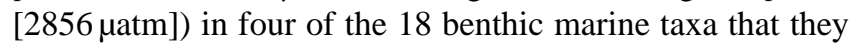
examined.

Enhanced calcification of the two species with a hyaline shell at intermediate $p \mathrm{CO}_{2}$ levels may be related to increases in the concentrations of dissolved inorganic carbon (in particular, of bicarbonate ions; Table 1). However, ${ }^{14} \mathrm{C}$ tracer studies of inorganic carbon uptake by the perforate (hyaline) foraminifer Amphistegina lobifera demonstrated that only a very small increase of uptake was observed at inorganic carbon concentrations higher than those of present seawater (ter Kuile et al., 1989). This is possibly because regardless of external $\mathrm{pH}$ and carbonate chemistry, the intracellular $\mathrm{pH}$ and the ratio between dissolved carbon dioxide, bicarbonate, and carbonate ions can be modified by foraminiferal protoplasm (Bentov et al., 2009; de Nooijer et al., 2009).

Photosynthesis by algal symbionts may be enhanced under intermediate $p \mathrm{CO}_{2}$ levels. The photosynthesis by algal symbionts provides host foraminifers with substantial photosynthates, which become a source of energy for metabolic activity (Hallock, 2000). In addition, photosynthates (carbohydrates) may be used for the organic matrix in foraminiferal shells, which is critical in initiating and directing chamber formation (Hallock, 1999). The removal of host metabolites such as $\mathrm{NH}_{4}^{+}$and $\mathrm{PO}_{4}^{3-}$ by symbionts might aid calcification of the host foraminifers because such metabolites can interfere with crystal formation (ter Kuile et al., 1989). Thus, enhanced photosynthesis by algal symbionts may promote protoplasmic growth and chamber formation (i.e. $\mathrm{CO}_{2}$ fertilization effects). Enhancement of calcification by photosynthesis has been also demonstrated by Iglesias-Rodrigues et al. (2008) in E. huxleyi, and suggested by Ries et al. (2009) in coralline red and calcareous green algae. Although other experimental results have suggested that photosynthesis by isolated in situ diatom symbionts is saturated at the inorganic carbon concentration of the present seawater (ter Kuile et al., 1989), further studies are needed to measure photosynthetic rates of algal symbionts at various $p \mathrm{CO}_{2}$ levels.

In contrast to $B$. sphaerulata and $C$. gaudichaudii, calcification in A. hemprichii did not increase significantly at intermediate $p \mathrm{CO}_{2}$ levels. A declining calcification trend of A. hemprichii at intermediate $p \mathrm{CO}_{2}$ levels is possibly attributed to the decrease in carbonate concentration. Culture experiments using ${ }^{14} \mathrm{C}$ tracer techniques showed that uptake of dissolved inorganic carbon into the shell of A. hemprichii increased linearly as a function of the carbonate concentration (ter Kuile et al., 1989). Therefore, for this species, seawater carbonate chemistry may largely influence calcification, compared with $\mathrm{CO}_{2}$ fertilization effects discussed above.

Calcification in all three species studied tended to be reduced at the highest $p \mathrm{CO}_{2}$ level $(970 \mu \mathrm{atm})$. These results suggest that $p \mathrm{CO}_{2}$ levels of around $1000 \mu \mathrm{atm}$ and higher ( $\mathrm{pH}$ of 7.7 on the seawater scale) are a limiting factor for $\mathrm{CO}_{2}$ fertilization effects for the two hyaline species. Le Cadre et al. (2003) showed that in low pH seawater, pseudopodial emission of a hyaline species (Ammonia) was reduced or stopped, implying a disturbance of the metabolic activity of the foraminifer. Further studies are needed to investigate metabolic activity in relation to chamber formation (calcification) of symbiont-bearing foraminifers in high $p \mathrm{CO}_{2}$ seawater.

Although not all observations were statistically significant, calcification tended to decrease from $p \mathrm{CO}_{2}$ of 260 to $360 \mu \mathrm{atm}$ in the three species examined. Culture experiments using ${ }^{14} \mathrm{C}$ tracer techniques (ter Kuile et al., 1989) have demonstrated that in perforate species (A. lobifera) the optimum $\mathrm{pH}$ for calcification is between $\mathrm{pH} 8.2$ and 8.9 (NBS scale), but in an imperforate species (A. hemprichii), they found no optimum $\mathrm{pH}$ for calcification, which increased very steeply above $\mathrm{pH} 8.4$ (NBS scale). These results indicate that reef foraminifers with both hyaline and porcelaneous shells can calcify more effectively in seawater at a $\mathrm{pH}$ higher than the present level.

Our findings suggest that ongoing ocean acidification favor symbiont-bearing reef foraminifers with hyaline shells at intermediate $p \mathrm{CO}_{2}$ levels (580 to $770 \mu \mathrm{atm}$ ) but be unfavorable to those with either hyaline or porcelaneous shells at higher $p \mathrm{CO}_{2}$ levels. In future, relatively high calcification rates of symbiont-bearing hyaline foraminifers but low calcification rates of porcelaneous ones compared with previous rates may be attributed to ocean acidification. These contrasting differences in calcification rates may lead to the 
dominance of hyaline foraminifers over porcelaneous ones in symbiont-bearing reef foraminiferal communities.

This possibility also explains the dominance of large benthic foraminifers with hyaline shells during the warm period of the Cenozoic. Atmospheric $\mathrm{CO}_{2}$ concentrations were more than $1000 \mathrm{ppm}$ for the Paleocene and early Eocene, then declined into the middle Eocene (Pearson and Palmer, 2000; Demicco et al., 2003). Although large benthic foraminifers diversified following the terminal Cretaceous extinctions, a reduction of the genetic diversity and a simultaneous diversification at species level and a considerable increase of their shell size and adult dimorphism, which are referred to as a larger foraminiferal turnover, appears to have been coeval with the Late Paleocene Thermal Maximum (Orue-Etxebarria et al., 2001), when atmospheric $\mathrm{CO}_{2}$ exceeded over 2000 ppm (Pearson and Palmer, 2000; Demicco et al., 2003). During the middle Eocene, when atmospheric $\mathrm{CO}_{2}$ levels were similar to or higher than present (Pearson and Palmer, 1999), large benthic foraminifers with hyaline shells such as Nummulites extremely diversified and dominated tropical, shallow-water carbonate environments (Hallock et al., 1991). Their modern descendants host diatom symbionts in tropical shelf environments (Lee, 1998). Thus, diversification and predominance of hyaline, large benthic foraminifers during the middle Eocene may partly be explained by relatively high $p \mathrm{CO}_{2}$, which induced $\mathrm{CO}_{2}$ fertilization effects by algal symbionts.

Acknowledgements. This research was supported by the Global Environmental Research Fund of the Ministry of the Environment, Japan (No. A-0804, Principal Investigator: Y. Nojiri). We are grateful to Y. Shirayama for their discussion, to A. Iguchi, S. Ohki, and S. Ozaki for their help with the maintenance of the highprecision $p \mathrm{CO}_{2}$ control system, to T. Ono for his assistance with seawater measurements, and to Y. Yoshinaga and T. Ishimura for their help with shell weight measurements. Constructive comments from Dr. J. Hohenegger and Dr. L. J. de Nooijer greatly improved the early version of the manuscript.

Edited by: H. Kitazato

\section{References}

Barker, S. and Elderfield, H.: Foraminiferal calcification response to glacial-interglacial changes in atmospheric $\mathrm{CO}_{2}$, Science, 297, 833-836, doi:10.1126/science.1072815, 2002.

Bentov, S., Brownlee, C., and Erez, J.: The role of seawater endocytosis in the biomineralization process in calcareous foraminifera, P. Natl. Acad. Sci. USA, 106, 21500-21504, doi:10.1073/pnas.0906636106, 2009.

Bijma, J., Spero, H., and Lea, D.: Reassessing foraminiferal stable isotope geochemistry: impact of the oceanic carbonate system (experimental results), in: Use of Proxies in Paleoceanography: Examples from the South Atlantic, edited by: Fischer, G. and Wefer, G., Springer-Verlag, Berlin, Heidelberg, Germany, 489512, 1999.
Bijma, J., Honisch, B., and Zeebe, R.: Impact of the ocean carbonate chemistry on living foraminiferal shell weight: comment on "Carbonate ion concentration in glacial-age deepwaters of the Caribbean Sea", edited by: W. S. Broecker and E. Clark, Geochem. Geophys. Geosyst., 3, 1064, 2002.

de Moel, H., Ganssen, G. M., Peeters, F. J. C., Jung, S. J. A., Kroon, D., Brummer, G. J. A., and Zeebe, R. E.: Planktic foraminiferal shell thinning in the Arabian Sea due to anthropogenic ocean acidification?, Biogeosciences, 6, 1917-1925, doi:10.5194/bg-61917-2009, 2009.

de Nooijer, L. J., Toyofuku, T., and Kitazato, H.: Foraminifera promote calcification by elevating their intracellular pH, P. Natl. Acad. Sci. USA, 106, 15374-15378, doi:10.1073/pnas.0904306106, 2009.

de Vargas, C., Bonzon, M., Rees, N. W., Pawlowski, J., and Zaninetti, L.: A molecular approach to biodiversity and biogeography in the planktonic foraminifer Globigerinella siphonifera (d'Orbigny), Mar. Micropaleontol., 45, 101-116, doi:10.1016/s0377-8398(02)00037-3, 2002.

Dissard, D., Nehrke, G., Reichart, G. J., and Bijma, J.: Impact of seawater $p \mathrm{CO}_{2}$ on calcification and $\mathrm{Mg} / \mathrm{Ca}$ and $\mathrm{Sr} / \mathrm{Ca}$ ratios in benthic foraminifera calcite: results from culturing experiments with Ammonia tepida, Biogeosciences, 7, 81-93, doi:10.5194/bg-7-81-2010, 2010.

Demicco, R. V., Lowenstein, T. K., and Hardie, L. A.: Atmospheric $p \mathrm{CO}_{2}$ since $60 \mathrm{Ma}$ from records of seawater $\mathrm{pH}$, calcium, and primary carbonate mineralogy, Geology, 31, 793-796, doi:10.1130/g19727.1, 2003.

Erez, J.: The source of ions for biomineralization in foraminifera and their implications for paleoceanographic proxies, Rev. Mineral. Geochem., 54, 115-149, doi:10.2113/0540115, 2003.

Fabry, V. J.: Marine calcifiers in a high- $\mathrm{CO}_{2}$ ocean, Science, 320, 1020-1022, doi:10.1126/science.1157130, 2008.

Fujita, K. and Fujimura, H.: Organic and inorganic carbon production by algal symbiont-bearing foraminifera on northwest pacific coral-reef flats, J. Foramin. Res., 38, 117-126, doi:10.2113/gsjfr.38.2.117, 2008.

Gattuso, J. P., Frankignoulle, M., Bourge, I., Romaine, S., and Buddemeier, R. W.: Effect of calcium carbonate saturation of seawater on coral calcification, Global Planet. Change, 18, 37-46, 1998.

Hallock, P.: Production of carbonate sediments by selected large benthic foraminifera on two Pacific coral reefs, J. Sediment. Petrol., 51, 467-474, 1981.

Hallock, P.: Symbiont-bearing foraminifera, in: Modern Foraminifera, edited by: Sen Gupta, B. K., Kluwer Academic Publishers, Dordrecht, Netherlands, 123-139, 1999.

Hallock, P.: Symbiont-bearing foraminifera: harbingers of global change?, Micropaleontology, 46, 95-104, 2000.

Hallock, P., Forward, L. B., and Hansen, H. J.: Influence of environment on the test shape of Amphistegina, J. Foramin. Res., 16, 224-231, 1986.

Hallock, P., Premoli Silva, I., and Boersma, A.: Similarities between planktonic and larger foraminiferal evolutionary trends through Paleogene paleoceanographic changes, Palaeogeogr., Palaeoclimatol., Palaeoecol., 83, 49-64, 1991.

Hoegh-Guldberg, O., Mumby, P. J., Hooten, A. J., Steneck, R. S., Greenfield, P., Gomez, E., Harvell, C. D., Sale, P. F., Edwards, A. J., Caldeira, K., Knowlton, N., Eakin, C. M., Iglesias-Prieto, 
R., Muthiga, N., Bradbury, R. H., Dubi, A., and Hatziolos, M. E.: Coral reefs under rapid climate change and ocean acidification, Science, 318, 1737-1742, doi:10.1126/science.1152509, 2007.

Hohenegger, J.: Distribution of living larger foraminifera NW of Sesoko-jima, Okinawa, Japan, P.S.Z.N. I: Mar. Ecol., 15, 291334, 1994.

Hohenegger, J.: The importance of symbiont-bearing benthic foraminifera for West Pacific carbonate beach environments, Mar. Micropaleontol., 61, 4-39, 2006.

Iglesias-Rodriguez, M. D., Halloran, P. R., Rickaby, R. E. M., Hall, I. R., Colmenero-Hidalgo, E., Gittins, J. R., Green, D. R. H., Tyrrell, T., Gibbs, S. J., von Dassow, P., Rehm, E., Armbrust, E. V., and Boessenkool, K. P.: Phytoplankton calcification in a high- $\mathrm{CO}_{2}$ world, Science, 320, 336-340, doi:10.1126/science.1154122, 2008.

Kleypas, J. A., Buddemeier, R. W., Archer, D., Gattuso, J. P., Langdon, C., and Opdyke, B. N.: Geochemical consequences of increased atmospheric carbon dioxide on coral reefs, Science, 284, 118-120, 1999.

Kuffner, I. B., Andersson, A. J., Jokiel, P. L., Rodgers, K. S., and Mackenzie, F. T.: Decreased abundance of crustose coralline algae due to ocean acidification, Nat. Geosci., 1, 114-117, doi:10.1038/ngeo100, 2008.

Kuroyanagi, A., Kawahata, H., Suzuki, A., Fujita, K., and Irie, T.: Impacts of ocean acidification on large benthic foraminifers: results from laboratory experiments, Mar. Micropaleontol., 73, 190-195, doi:10.1016/j.marmicro.2009.09.003, 2009.

Langer, G., Nehrke, G., Probert, I., Ly, J., and Ziveri, P.: Strain-specific responses of Emiliania huxleyi to changing seawater carbonate chemistry, Biogeosciences, 6, 2637-2646, doi:10.5194/bg-6-2637-2009, 2009.

Langer, M. R., Silk, M. T., and Lipps, J. H.: Global ocean carbonate and carbon dioxide production: the role of reef foraminifera, $\mathrm{J}$. Foramin. Res., 27, 271-277, 1997.

Le Cadre, V., Debenay, J. P., and Lesourd, M.: Low pH effects on Ammonia beccarii test deformation: implications for using test deformations as a pollution indicator, J. Foramin. Res., 33, 1-9, 2003.

Lee, J. J.: "Living sands"-larger foraminifera and their endosymbiotic algae, Symbiosis, 25, 71-100, 1998.

Lee, J. J., Sang, K., ter Kuile, B., Strauss, E., Lee, P. J., and Faber, W. W.: Nutritional and related experiments on laboratory maintenance of three species of symbiont-bearing, large foraminifera, Mar. Biol., 109, 417-425, doi:10.1007/bf01313507, 1991.

Lombard, F., da Rocha, R. E., Bijma, J., and Gattuso, J.-P.: Effect of carbonate ion concentration and irradiance on calcification in planktonic foraminifera, Biogeosciences, 7, 247-255, doi:10.5194/bg-7-247-2010, 2010.

Meehl, G. A., Stocker, T. F., Collins, W. D., Friedlingstein, P., Gaye, A. T., Gregory, J. M., Kitoh, A., Knutti, R., Murphy, J. M., Noda, A., Raper, S. C. B., Watterson, I. G., Weaver, A. J., and Zhao, Z.-C.: Global climate projections, in: Climate Change 2007: The Physical Science Basis. Contribution of Working Group I to the Fourth Assessment Report of the Intergovernmental Panel on Climate Change, edited by: Solomon, S., Qin, D., Manning, M., Chen, Z., Marquis, M., Averyt, K. B., Tignor, M., and Miller, H. L., Cambridge University Press, Cambridge, United Kingdom and New York, NY, USA, 747-845, 2007.
Morse, J. W., Andersson, A. J., and Mackenzie, F. T.: Initial responses of carbonate-rich shelf sediments to rising atmospheric $p \mathrm{CO}_{2}$ and "ocean acidification": Role of high Mg-calcites, Geochim. Cosmochim. Acta, 70, 5814-5830, doi:10.1016/j.gca.2006.08.017, 2006.

Moy, A. D., Howard, W. R., Bray, S. G., and Trull, T. W.: Reduced calcification in modern Southern Ocean planktonic foraminifera, Nat. Geosci., 2, 276-280, doi:10.1038/Ngeo460, 2009.

Orr, J. C., Fabry, V. J., Aumont, O., Bopp, L., Doney, S. C., Feely, R. A., Gnanadesikan, A., Gruber, N., Ishida, A., Joos, F., Key, R. M., Lindsay, K., Maier-Reimer, E., Matear, R., Monfray, P., Mouchet, A., Najjar, R. G., Plattner, G.-K., Rodgers, K. B., Sabine, C. L., Sarmiento, J. L., Schlitzer, R., Slater, R. D., Totterdell, I. J., Weirig, M.-F., Yamanaka, Y., and Yool, A.: Anthropogenic ocean acidification over the twenty-first century and its impact on calcifying organisms, Nature, 437, 681-686, 2005.

Orue-Etxebarria, X., Pujalte, V., Bernaola, G., Apellaniz, E., Baceta, J. I., Payros, A., Nuñez-Betelu, K., Serra-Kiel, J., and Tosquella, J.: Did the Late Paleocene thermal maximum affect the evolution of larger foraminifers? Evidence from calcareous plankton of the Campo Section (Pyrenees, Spain), Mar. Micropaleontol., 41, 45-71, doi:10.1016/s0377-8398(00)00052-9, 2001.

Pearson, P. N. and Palmer, M. R.: Middle Eocene seawater $\mathrm{pH}$ and atmospheric carbon dioxide concentrations, Science, 284, 1824 1826, doi:10.1126/science.284.5421.1824, 1999.

Pearson, P. N. and Palmer, M. R.: Atmospheric carbon dioxide concentrations over the past 60 million years, Nature, 406, 695-699, 2000.

Raja, R., Saraswati, P. K., Rogers, K., and Iwao, K.: Magnesium and strontium compositions of recent symbiont-bearing benthic foraminifera, Mar. Micropaleontol., 58, 31-44, 2005.

Ridgwell, A., Schmidt, D. N., Turley, C., Brownlee, C., Maldonado, M. T., Tortell, P., and Young, J. R.: From laboratory manipulations to Earth system models: scaling calcification impacts of ocean acidification, Biogeosciences, 6, 2611-2623, doi:10.5194/bg-6-2611-2009, 2009.

Ries, J. B., Cohen, A. L., and McCorkle, D. C.: Marine calcifiers exhibit mixed responses to $\mathrm{CO}_{2}$-induced ocean acidification, $\mathrm{Ge}$ ology, 37, 1131-1134, doi:1131-1134.10.1130/g30210a.1, 2009.

Röttger, R. and Krüger, R.: Observations on the biology of Calcarinidae (Foraminiferida), Mar. Biol., 106, 419-425, 1990.

Sabine, C. L., Feely, R. A., Gruber, N., Key, R. M., Lee, K., Bullister, J. L., Wanninkhof, R., Wong, C. S., Wallace, D. W. R., Tilbrook, B., Millero, F. J., Peng, T.-H., Kozyr, A., Ono, T., and Rios, A. F.: The Oceanic sink for anthropogenic $\mathrm{CO}_{2}$, Science, 305, 367-371, doi:10.1126/science.1097403, 2004.

Sakai, K. and Nishihira, M.: Population study of the benthic foraminifer Baculogypsina sphaerulata on the Okinawan reef flat and preliminary estimation of its annual production, in: Proceedings of the 4th International Coral Reef Symposium, volume 2, Manila, 18-22 May 1981, 763-766, 1981.

Saraswati, P. K., Seto, K., and Nomura, R.: Oxygen and carbon isotopic variation in co-existing larger foraminifera from a reef flat at Akajima, Okinawa, Japan, Mar. Micropaleontol., 50, 339 349, doi:10.1016/S0377-8398(03)00099-9, 2004. 
K. Fujita et al.: Effects of ocean acidification on calcification

Suzuki, A.: Seawater $\mathrm{CO}_{2}$ system and its transformation caused by photosynthesis and calcification in coral reefs. - theory and measurements of reef metabolisms -, Bull. Geol. Surv. Japan, 45, 573-623, 1994. ter Kuile, B., Erez, J., and Padan, E.: Mechanisms for the uptake of inorganic carbon by two species of symbiont-bearing foraminifera, Mar. Biol., 103, 241-251, 1989. 